\title{
Cryomicroscopic Investigations of Freezing Processes in Cell Suspensions
}

\author{
Tathagata Acharya and Ram V. Devireddy*
}

Bioengineering Laboratory, Department of Mechanical Engineering, Louisiana State University, Baton Rouge, LA, USA

\begin{abstract}
This study evaluates the freezing response of three different cell types, Pacific oyster embryos $(\sim 50 \mu \mathrm{m}$ in diameter), Jurkat cells and HeLa cells ( $\sim 12$ to $15 \mu \mathrm{m}$ 's in diameter), using cryomicroscopy. Freezing experiments were performed on oyster embryos at cooling rates of either 5 or $10{ }^{\circ} \mathrm{C} / \mathrm{min}$, while Jurkats were cooled at either 1 or $10{ }^{\circ} \mathrm{C} / \mathrm{min}$ and HeLa cells were cooled at either 1,15 or $20{ }^{\circ} \mathrm{C} / \mathrm{min}$, respectively. The experiments with oyster embryos were primarily designed to investigate the phenomena of intracellular ice formation (IIF) while the experiments for Jurkat and HeLa cells were designed to investigate both cellular dehydration and IIF during freezing. IIF was characterized by the abrupt black flashing during the cooling steps while the cellular dehydration experiments were characterized by the volumetric (projected area) shrinkage of the cells during the cooling steps. Mathematical models were fit to the cellular dehydration data to obtain the Jurkat and HeLa cell membrane permeability $\left(L_{p g}\right)$ at the reference temperature $(273.15 \mathrm{~K})$, the apparent activation energy of the cellular dehydration process $\left(E_{L p}\right)$ or the temperature dependence of $L_{p g}$. The temperature dependence of IIF in the oyster embryos, the Jurkat cells and the HeLa cells were also determined.
\end{abstract}

Keywords: Intracellular ice formation, water transport or cellular dehydration, pacific oyster embryos, HeLa cells, jurkat cells.

\section{INTRODUCTION}

Cryopreservation refers to the technique of storing a living organism at extremely low temperatures in suspended animation, for long periods of time, so that it may be revived and restored to the same living state. Cryopreservation techniques have already been shown to be useful in a variety of mammalian systems such as lymphocytes, platelets, granulocytes, gametes, hepatocytes, bone marrow stem cells, cornea and skin, pancreatic tissue, human and non-human mammalian oocytes, tissue engineered equivalents, adult stem cells, insects, fish, micro-organisms and algae, rat and human liver slices [1-12]. Alternatively, as demonstrated by Dr. James Arnott and co-investigators in the 1850s, cold temperatures could also be used for the treatment of malignant tumors, a process termed as cryosurgery [13-20].

Both cryopreservation and cryosurgery require an understanding of the relationship between the biological system being frozen and the applied cooling stress. When the cell in a solution is subjected to a cooling protocol, the initial ice formation takes place in the extracellular space. The cell membrane acts as a barrier and prevents ice formation inside the cell resulting in super-cooling of the intracellular water. The unfrozen super-cooled intracellular water remains at a higher chemical potential than the partially frozen extracellular solution [20-24]. This leads to thermodynamic nonequilibrium and provides the driving force for the two biophysical processes during freezing, either cellular dehydration (water transport) or intracellular ice formation, IIF [2226]. Extensive data suggests that at "slow" cooling rates water transport is the dominant mechanism while IIF is the

*Address correspondence to this author at the Bioengineering Laboratory, Department of Mechanical Engineering, Louisiana State University, Baton Rouge, LA, USA; Tel: 1-225-578-5891; Fax: 1-225-578-5924;

E-mail: devireddy@me.lsu.edu dominant mechanism at "rapid" cooling rates [25-30]. Both cellular water transport and IIF have been proved to be deleterious to the post-thaw survival of biological systems and an optimal cooling rate exists between these two extremes [2432]. For example, when the cooling rate is slow, the intracellular water has enough time to flow out of the cell through the semi-permeable membrane and join the extracellular space. This results in changes in the extracellular region, such as in $\mathrm{pH}$ and ionic concentrations and potentially causes the tertiary structure of proteins to unfold. Hence, some of the original properties of the cell (and its internal structures) are either diminished or eliminated [20-32]. Additional damage may also take place through the mechanical interactions between the extracellular ice crystals and cells [33]. On the other hand, IIF is generally considered to be lethal as it causes injury to the intracellular structures and the cell membrane [20-32]. Thus, the balance between the membrane's water permeability and the probability of IIF results in different optimal cooling rates for different cells, i.e. the exact magnitude of the "slow" and "rapid" cooling is dependent upon the cell type and needs to be experimentally determined.

In this work, the responses of three different cell types (Pacific oyster embryos, Jurkat and HeLa cells) to an imposed cooling stress were evaluated using cryomicroscopy. Prior cryopreservation studies on aquatic cells (gametes and embryos) are quite extensive and were conducted to assist selective breeding programs [34-41]. For example, SalinasFlores et al. [42], determined the membrane permeability characteristics of Pacific oyster oocytes and the development of optimized methods to add and remove a cryoprotective agent (ethylene glycol). Lin et al. [43] studied the effects of cooling rate, choice of cryoprotectant, and the seeding temperature on the survival of oyster embryos. The second cell type used in this study the Jurkat cells are routinely used to study $\mathrm{T}$ cell leukemia, $\mathrm{T}$ cell signaling and the expression of 
various chemokine receptors [44]. But prior cryobiological work on Jurkat cells is limited [45]. There is an increasing need to understand the low temperature behavior of Jurkat cells not only for immunological reasons but also for the application in adoptive tumor therapy [46]. And finally, like Jurkat cells, HeLa cells are also an immortal cell line derived from cervical cancer cells [47]. Similar to Jurkat cells, these cells were also chosen for analysis because of their robustness, easy availability, and because they are relatively less understood among the cancer cells.

\section{MATERIALS AND METHODS}

\section{Cryomicroscopy Experiments}

Cryomicroscopy involves application of cryogenic temperatures to cellular systems mounted under a light microscope to study the biophysical response of cells to freezing. This technique has been refined and modified over years to study the dynamic response of a variety of plant and mammalian cells under various freezing conditions [48-62]. Some of the important advances in cryomicroscopy include the mounting of a cold stage on a microscope instead of cooling the entire microscope; the use of a digital control system in lieu of the less accurate analog control system; the use of video recordings to record the events during freezing; and the use of computer enhanced image analysis techniques to overcome the low resolution of the video recordings. Thus, the currently available cryomicroscopy systems integrate the functions of sample temperature control, image storage \& event correlation, and image analysis. Cryomicroscopy can, therefore, be used to obtain images of a dehydrating cell during the course of the freezing protocol. Hence, by calculating the change in surface area of a cell from its projected two dimensional image one can extrapolate it to the three dimensional change in cell volume (cellular dehydration) as a function of cooling rate and sub-zero temperature [48-62]. Cryomicroscopy also helps in characterizing IIF through visual inspection of the blackening of cells due to scattering of light by opaque ice inside the nucleated cells [48-62].

The cryomicroscopy experimental procedures utilized in the present study are similar to those described extensively in the literature [48-62] and were performed using a commercially available BCS-196 cryostage (Linkam Scientific $^{\mathrm{TM}}$, Surrey, UK). The Linkam ${ }^{\mathrm{TM}}$ cryostage is capable of controlled cooling and heating between $-125^{\circ} \mathrm{C}$ and $+160{ }^{\circ} \mathrm{C}$ at cooling/heating rates ranging from 0.1 to $130{ }^{\circ} \mathrm{C} / \mathrm{min}$ (Fig. 1A). Typically, the cryostage is cooled by a constant flow of liquid nitrogen; thus, equilibrating the cryostage at $\sim-160$ ${ }^{\circ} \mathrm{C}$. The cryostage temperatures are measured by platinum resistance thermocouples. A temperature controller maintains the cryostage at the desired pre-set temperature by utilizing electrical (power) heating, i.e., the amount of cooling due to the liquid nitrogen flow is adjusted and counterbalanced with electrical heaters. Hence, maintaining the cryostage at the desired temperature or set-point. A time varying temperature (or a desired cooling rate) can be created using temperature-control software that dynamically changed the amount of heating, i.e., the sample could either be cooled or heated by either decreasing or increasing the amount of heating. The cryostage (Fig. 1B) was mounted with a circular quartz crucible to hold the cell suspension during freezing. A cover-slip was placed on top of the cell suspension within the quartz crucible to prevent leakage/media evaporation and to ensure proper visibility of the cells during the freezing process. The Linkam ${ }^{\mathrm{TM}}$ cryostage was attached to a microscope (Nikon Eclipse E600, Nikon Instruments, NY) fitted with a Photometrics Coolsnap cf camera (Hamamatsu, Photonics, Bridgewater, NJ). During the experiments a live video signal was sent from the camera to the attached DELL personal computer and the images recorded with the help of commercially available Metacam software (Universal Imaging Corp., Buckinghamshire, UK).

\section{Image Analysis}

Image analysis of cells involved the evaluation of volumetric shrinkage of cells due to dehydration and evaluation of number of cells that underwent intracellular ice formation. Evaluation was based on the assumption that the cells were regular and spherical. The change in the diameter of the cell was measured after a dehydration experiment which was then utilized in evaluating the change in corresponding cellular volume [48-62]. For IIF experiments, the images obtained through the camera were stacked using the Metacam software to make movies. Usually a cluster of around 30-40 cells were focused under the microscope and were examined for blackening. The number of cells that turned black due to IIF at different temperatures through the protocol was noted. Percentage intracellular ice formation (P-IIF) was evaluated as the ratio of the number of cells that turned black due to IIF to the total number of cells and was plotted against temperature for different freezing rates.

\section{Pacific Oyster (Crassostrea gigas) Embryos}

Oyster embryos were obtained from a population of fertilized eggs, about 120 minutes after the artificial fertilization in sea water of $34+2 \%$ salinity at a temperature of $27 \pm 1$ ${ }^{\circ} \mathrm{C}$. Hundreds of oyster embryos were pooled from three females. A 10x D-PBS (Dulbecco's Phosphate Buffer Saline) solution was used as the cellular suspension media. The embryos were placed on a petri-dish to be examined under the cryomicroscope for an applied cooling stress. A group of embryos were focused under the cryomicroscope, and a predetermined freeze thaw protocol was used to examine their freezing response. The main aim of the experiment was to identify the freezing rates at which the cells showed darkening or flashing to reveal intracellular ice formation. The freezing protocol used for the oyster embryo experiments was:

Step 1: Cool the embryos from $23{ }^{\circ} \mathrm{C}$ to $4{ }^{\circ} \mathrm{C}$ at $5{ }^{\circ} \mathrm{C} / \mathrm{min}$

Step 2: Cool the embryos from $4{ }^{\circ} \mathrm{C}$ to $\sim-6{ }^{\circ} \mathrm{C}$ at 1 ${ }^{\circ} \mathrm{C} / \mathrm{min}$. Note that the phase change temperature of $10 \mathrm{x}$ D-PBS is $\sim-5.6^{\circ} \mathrm{C}$.

Step 3: Cool the embryos from $-6{ }^{\circ} \mathrm{C}$ to $-40{ }^{\circ} \mathrm{C}$ at either 5 or $10{ }^{\circ} \mathrm{C} / \mathrm{min}$.

Step 4: Heat the embryos from $-40{ }^{\circ} \mathrm{C}$ to $20{ }^{\circ} \mathrm{C}$ at either 5 or $10{ }^{\circ} \mathrm{C} / \mathrm{min}$.

\section{Jurkat Cells}

Jurkat cells were maintained in $25 \mathrm{~cm}^{2} \mathrm{~T}$-flasks (BD Falcon, Franklin Lanes, NJ) with $5 \mathrm{ml}$ of $\mathrm{HyQ}^{\circledR}$ RPMI-1640-reduced serum medium (RPMI-RS) supplemented with $3 \%$ fetal bovine serum (FBS) and incubated at $37{ }^{\circ} \mathrm{C}$ in a humidified 


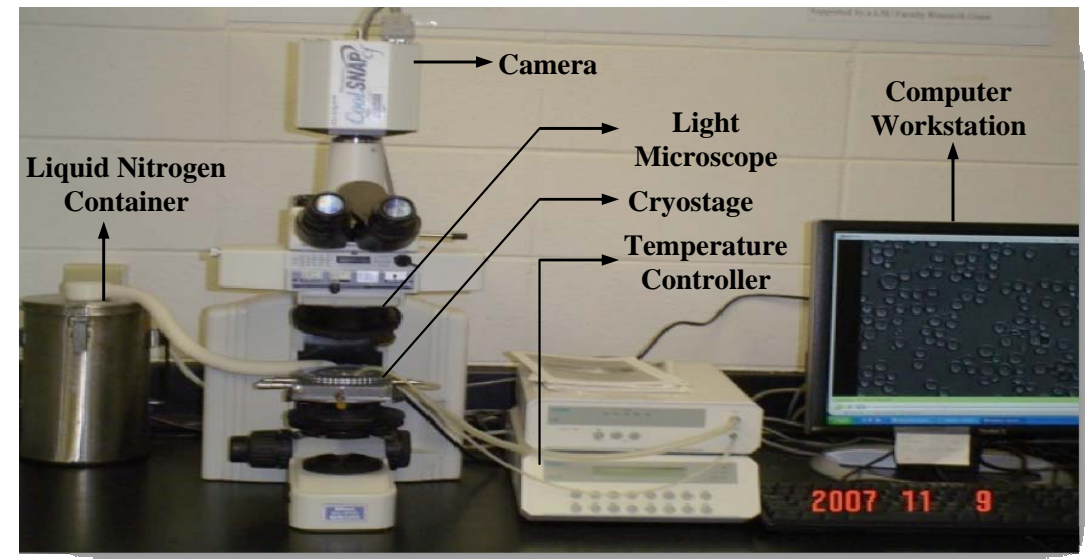

(A)

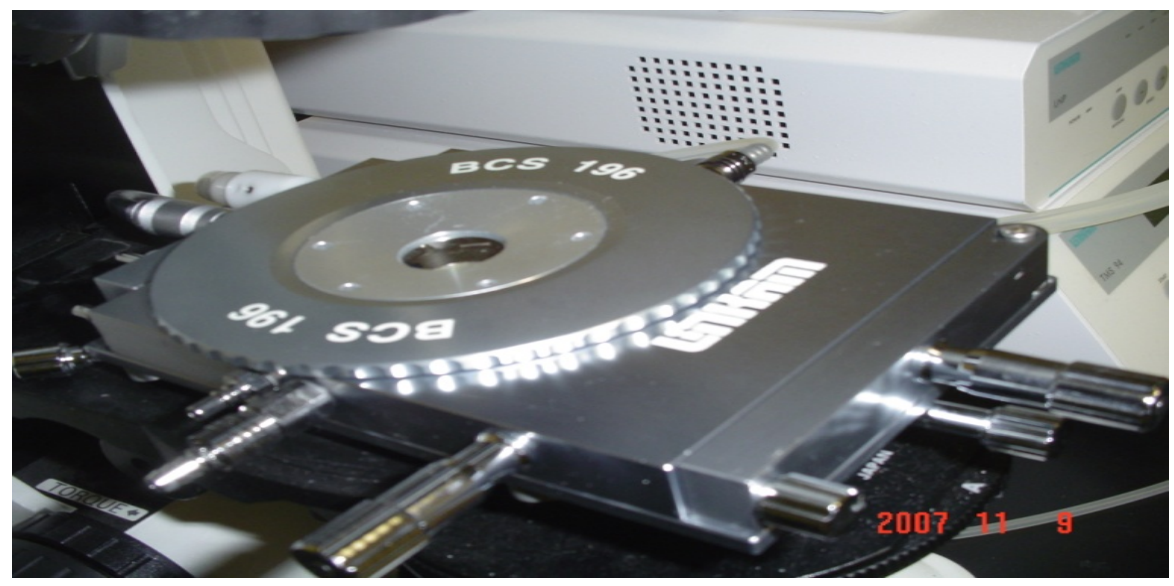

(B)

Fig. (1). A photomicrograph of the cryomicroscopy set up (1A) and the BCS-LINKAM cryostage (1B) is shown. Within the cryomicroscopy set up, the liquid nitrogen container, the camera, the light microscope, the cryostage, the temperature controller and the computer workstation for data/movie collection are labeled and shown.

atmosphere containing $5 \% \mathrm{CO}_{2}$. For cryomicroscopy experiments, Jurkat cells were transferred to a centrifuge tube and were spun down at $1900 \mathrm{rpm}$ for 5 minutes using Eppendorf Minispin Plus centrifuge. The pellet was resuspended in 1X Dulbecco's Phosphate Buffered Saline (DPBS) solution, which was considered isotonic for these cells. Experiments on Jurkat cells were performed at either 1 or $10{ }^{\circ} \mathrm{C} / \mathrm{min}$ in order to observe their response, at both "slow" and "fast" freezing rates. A typical freezing protocol used for the Jurkat cell experiments was:

\section{Step 1: Cool the Jurkats from $23{ }^{\circ} \mathrm{C}$ to $4{ }^{\circ} \mathrm{C}$ at $10{ }^{\circ} \mathrm{C} / \mathrm{min}$}

Step 2: Cool the Jurkats from $4{ }^{\circ} \mathrm{C}$ to $-1{ }^{\circ} \mathrm{C}$ at $1{ }^{\circ} \mathrm{C} / \mathrm{min}$ and equilibrate at $-1{ }^{\circ} \mathrm{C}$ for $1 \mathrm{~min}$ to facilitate extracellular ice nucleation. Note that the phase change temperature of $1 \mathrm{x}$ D-PBS is $\sim-0.6^{\circ} \mathrm{C}$.

Step 3: Cool the Jurkats from $-1{ }^{\circ} \mathrm{C}$ to $-30{ }^{\circ} \mathrm{C}$ at either 1 or $10{ }^{\circ} \mathrm{C} / \mathrm{min}$.

Step 4: Heat the Jurkats from $-30{ }^{\circ} \mathrm{C}$ to $20{ }^{\circ} \mathrm{C}$ at 10 ${ }^{\circ} \mathrm{C} / \mathrm{min}$.

\section{HeLa Cells}

HeLa cells were maintained in $25 \mathrm{~cm}^{2}$ flasks (BD Falcon, Franklin Lakes, NJ) with $5 \mathrm{ml}$ of Dulbecco's Modified Eagle's medium-reduced serum (DMEM-RS) supplemented with $3 \%$ fetal bovine serum (FBS) and incubated at $37{ }^{\circ} \mathrm{C}$ in a humidified atmosphere containing $5 \% \quad \mathrm{CO}_{2}$. HeLa cells were plated at a density of 80,000 cells per $\mathrm{cm}^{2}$ in 12 well cultured plates (BD Falcon, Franklin Lakes, NJ) and were allowed to adhere and grow for $24 \mathrm{~h}$ prior to trypsinization $(0.25 \%$ Trypsin $)$. In order to prepare the cells for experiments, the following steps were followed: i) aspiration of cell growth media from T-flask to waste; ii) addition of $5 \mathrm{ml}$ of 1x D-PBS; iii) addition of $5 \mathrm{ml}$ of Trypsin and equilibration for 10 mins. This facilitates the detachment of the HeLa cells from the T-flask substrate; iv) addition of $5 \mathrm{ml}$ of DMEM-RS (reduced serum) with 3\% Fetal Bovine Serum (FBS) to prevent further deleterious trypsinization; v) transfer of HeLa cells suspension to a $50 \mathrm{ml}$ centrifuge tube; vi) spin down of cells at $2400 \mathrm{rpm}$ for 5 min using an Eppendorf Minispin Plus centrifuge; vii) decant off the supernatant and 
re-suspend the HeLa cells in 1x D-PBS. Experiments on HeLa cells were performed at either 1,15 or $20{ }^{\circ} \mathrm{C} / \mathrm{min}$ in order to observe their response, at both "slow" and "fast" freezing rates. A typical freezing protocol used for the HeLa cell experiments was:

\section{Step 1: Cool the HeLas from $23{ }^{\circ} \mathrm{C}$ to $4{ }^{\circ} \mathrm{C}$ at $10{ }^{\circ} \mathrm{C} / \mathrm{min}$}

Step 2: Cool the HeLas from $4{ }^{\circ} \mathrm{C}$ to $-1{ }^{\circ} \mathrm{C}$ at $1{ }^{\circ} \mathrm{C} / \mathrm{min}$ and equilibrate at $-1{ }^{\circ} \mathrm{C}$ for $1 \mathrm{~min}$ to facilitate extracellular ice nucleation. Note that the phase change temperature of $1 \mathrm{x}$ D-PBS is $\sim-0.6^{\circ} \mathrm{C}$.

Step 3: Cool the HeLas from $-1{ }^{\circ} \mathrm{C}$ to $-30{ }^{\circ} \mathrm{C}$ at either 1 , 15 or $20^{\circ} \mathrm{C} / \mathrm{min}$.

Step 4: Heat the HeLas from $-30{ }^{\circ} \mathrm{C}$ to $20{ }^{\circ} \mathrm{C}$ at 10 ${ }^{\circ} \mathrm{C} / \mathrm{min}$.

\section{Water Transport Model for Jurkat and HeLa Cells}

The general model of water transport during freezing in single cell systems is reviewed elsewhere [63]. The model predicts the change of the cell volume with decreasing temperature $\mathrm{T}$ after ice has formed outside of an unfrozen cell. This is depicted mathematically as:

$d V / d T=\operatorname{Lp} A R T\left(C_{i}-C_{o}\right) / B$,

where $L_{p}$ is the water permeability of the cell plasma membrane, $\mathrm{A}$ is the surface area of the cell, $\mathrm{R}$ is the gas constant, $C_{i}$ and $C_{o}$ are the concentrations (osmotic potentials) of the intracellular and extracellular (unfrozen fractions) respectively, and $\mathrm{B}$ is the cooling rate of the protocol $\left({ }^{\circ} \mathrm{C} / \mathrm{min}\right)$. The cell membrane permeability, $L_{p}=$ fn $\left(L_{p g}, E_{L p}\right)$, itself depends on two biophysical parameters, $L_{p g}$, the reference water permeability at the phase change temperature of water, and $E_{L p}$, the activation energy for the water transport process [64]. Since the temperature, time, geometry and concentrations are all known in the experiment, the only unknowns in the equation are $L_{p g}$ and $E_{L p}$ which are called the biophysical parameters of water transport. These parameters $\left(L_{p g}\right.$ and $\left.E_{L p}\right)$ can be determined by a curve fit of the water transport equation to the experimental data as previously described [9-11, 30-32, $65,66]$. Once determined, these biophysical parameters can be incorporated into a recently developed Generic Optimal Cooling Rate Equation (GOCRE) that defines the optimal cooling rate $B_{\text {opt }}\left(\right.$ in ${ }^{\circ} \mathrm{C} / \mathrm{min}$ ) as [66]:

$B_{o p t}=1009.5 \bullet \exp ^{\left(-0.0546 \bullet E_{L p}\right)} \bullet\left(L_{p g}\right) \bullet\left(\frac{A}{W V}\right)$.

In the GOCRE, $L_{p g}$ and $E_{L p}$ represent the membrane permeability parameters (in $\mu \mathrm{m} / \mathrm{min}$-atm and $\mathrm{Kcal} / \mathrm{mole}$, respectively), while the term $\mathrm{A} / \mathrm{WV}$ (in $\mu \mathrm{m}^{-1}$ ) represents the ratio of the available surface area for water transport (A) to the initial volume of intracellular water $\left(\mathrm{WV}=\mathrm{V}_{\mathrm{o}}-\mathrm{V}_{\mathrm{b}} ; \mathrm{V}_{\mathrm{o}}\right.$ is the isotonic or initial cell volume and $V_{b}$ is the osmotically inactive cell volume).

\section{RESULTS AND DISCUSSION}

\section{Pacific Oyster Embryos (IIF Measurements)}

During the cryomicroscopy experiments the embryos were checked for reduction in size or diameter which would have indicated dehydration or water transport. In addition, the embryos were also checked for IIF through sudden blackening or darkening. Cells undergoing IIF usually dem- onstrate darkening because of ice formation that deflects or restricts the passage of light through them. Thus, transforming them from transparent to opaque cells. During a typical experiment (See Fig. 2), a total of 40 oyster embryos were studied. The oyster embryos were found to be spheres with a diameter of $\sim 60 \mu \mathrm{m}$. Fig. (2A) shows an image that was taken at the beginning of the experiment and at room temperature $\left(\sim 23^{\circ} \mathrm{C}\right)$. The oyster embryos are clearly visible and appeared to be semi-transparent and the extracellular solution of $10 \mathrm{x}$ D-PBS also appear as a clear and transparent fluid. Fig. (2B) shows an image of the same cells (as in Fig. 2A) but now cooled to $-15{ }^{\circ} \mathrm{C}$ at $5{ }^{\circ} \mathrm{C} / \mathrm{min}$. Notice that the extracellular solution is now frozen and that some of the oysters are exhibiting IIF or darkening. Figs. (2C and 2D) represent the same cell population cooled at $5{ }^{\circ} \mathrm{C} / \mathrm{min}$ to $-18{ }^{\circ} \mathrm{C}$ and -19.9 ${ }^{\circ} \mathrm{C}$, respectively. Notice the progressive increase in the percentage of embryo's exhibiting IIF, i.e. cells that are exhibiting "blackening" or "darkening". Percentage of embryos exhibiting IIF (P-IIF) was evaluated as the ratio of the number of embryos that darkened (exhibited IIF) to the total number of embryos that were present in the field of view (See Fig. 3). As shown in Fig. (3), oyster embryos cooled at $5{ }^{\circ} \mathrm{C} / \mathrm{min}$ underwent IIF between $-6{ }^{\circ} \mathrm{C}$ and $-20{ }^{\circ} \mathrm{C}$ while embryos cooled at $10{ }^{\circ} \mathrm{C} / \mathrm{min}$ exhibited IIF between $-6{ }^{\circ} \mathrm{C}$ and $-18{ }^{\circ} \mathrm{C}$. Note that the cumulative fraction (\%) of cells exhibiting IIF was obtained from 8 to 10 separate experiments for each cooling rate with approximately 10 cells in the field of view per experiment and pooled as a single population per cooling rate. Since, the data is a representation of the cumulative fraction of cells experiencing IIF from all the experiments (or from a population of cells). Hence, no error bars are shown within Fig. (3).

It is, generally believed that IIF is a deleterious event, that is lethal to cells. Hence, knowledge of freezing rates that induce IIF in oyster embryos will reveal the range of "fast" cooling rates; in our studies these are cooling rates $\geq 5$ ${ }^{\circ} \mathrm{C} / \mathrm{min}$. Thus, in the absence of any cryoprotective agents it is essential that oyster embryos be cooled at rates slower than $5{ }^{\circ} \mathrm{C} / \mathrm{min}$, possibly as low as 1 or $2{ }^{\circ} \mathrm{C} / \mathrm{min}$. Unfortunately, additional experiments could not be conducted at the "slower" rates due to the restricted and seasonal availability of oyster embryos.

\section{Relevance to Oyster Embryo Cryopreservation}

Recent United States Department of Agriculture (USDA) statistics indicate that the commercial value of oyster embryos produced within the continental United States is greater than $\$ 100$ million per year. However, the total production has decreased from 1998 due to diseases and adverse weather conditions while, the consumption of oysters has jumped from an average of 22 pounds per person to $\sim 31$ pounds per person in the US. Thus, over the last decade, many researchers have made attempts to improve oyster hatcheries. Obviously newer methods of hatchery production needed to be developed in order to keep up with the growing demand. One possible solution might lie in developing successful cryopreservation protocols for preserving oyster spermatozoa and oocytes/embryos and enabling fertilization. Although there were some exceptions [34-43,67-69] the study of cryobiology was largely neglected in most aquatic species. For example, Salinas-Flores et al. [68] determined that the Pacific oyster oocytes behaved as ideal osmometers 


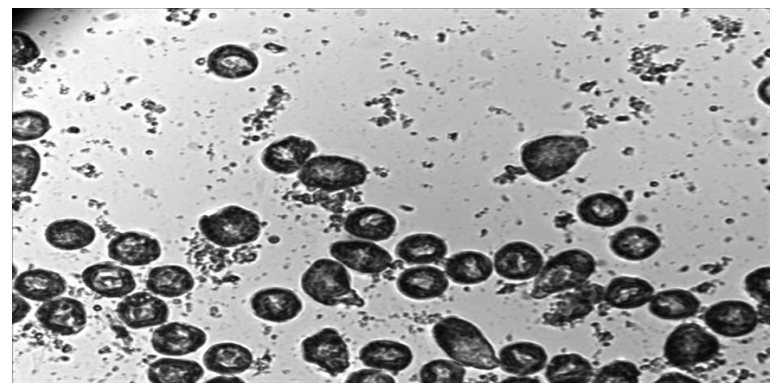

(A)

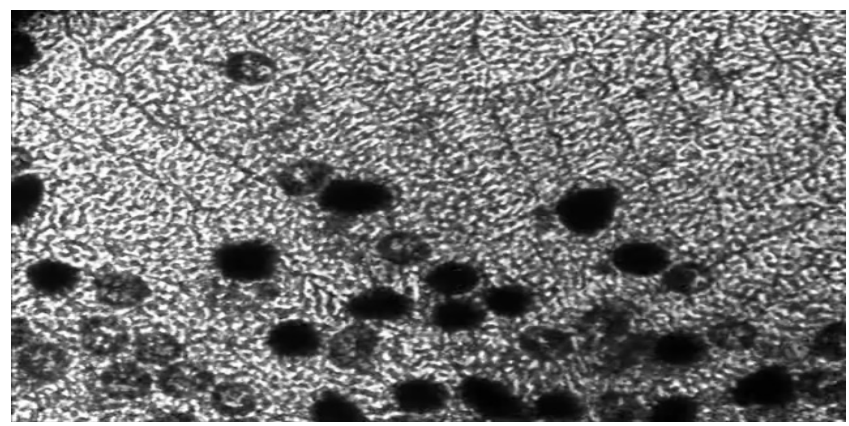

(C)

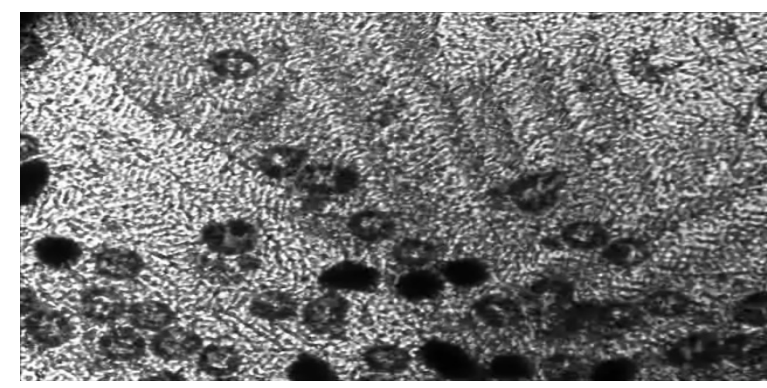

(B)

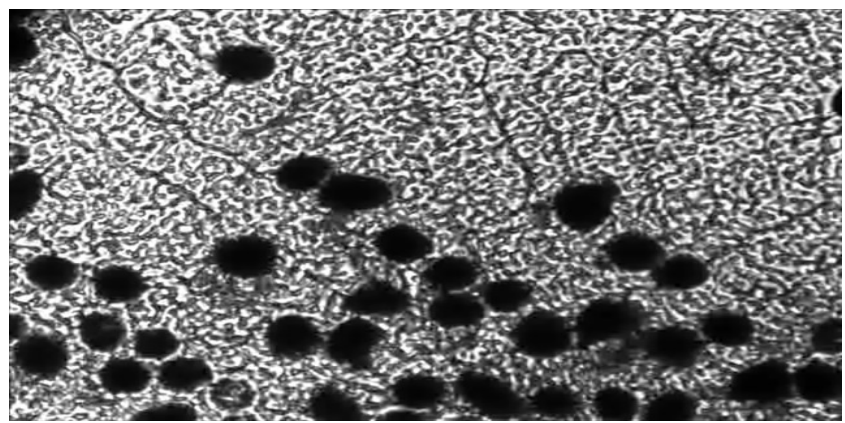

(D)

Fig. (2). Photomicrographs of Pacific oytser embryos being cooled at $5{ }^{\circ} \mathrm{C} / \mathrm{min}$ are shown at various temperatures. Specifically, at room temperature or $23{ }^{\circ} \mathrm{C}(\mathbf{2 A}),-15{ }^{\circ} \mathrm{C}(\mathbf{2 B}),-18{ }^{\circ} \mathrm{C}(2 \mathrm{C})$ and $-19.9{ }^{\circ} \mathrm{C}(\mathbf{2 D})$ are shown. Note the progressive increase in the number of cells exhibiting blackening or darkening associated with intracellular ice formation (IIF) as the sub-zero temperature is reduced, as shown in Figs. (2B to 2D). The formation of extracellular ice is evident in Figs. (2B to 2D).

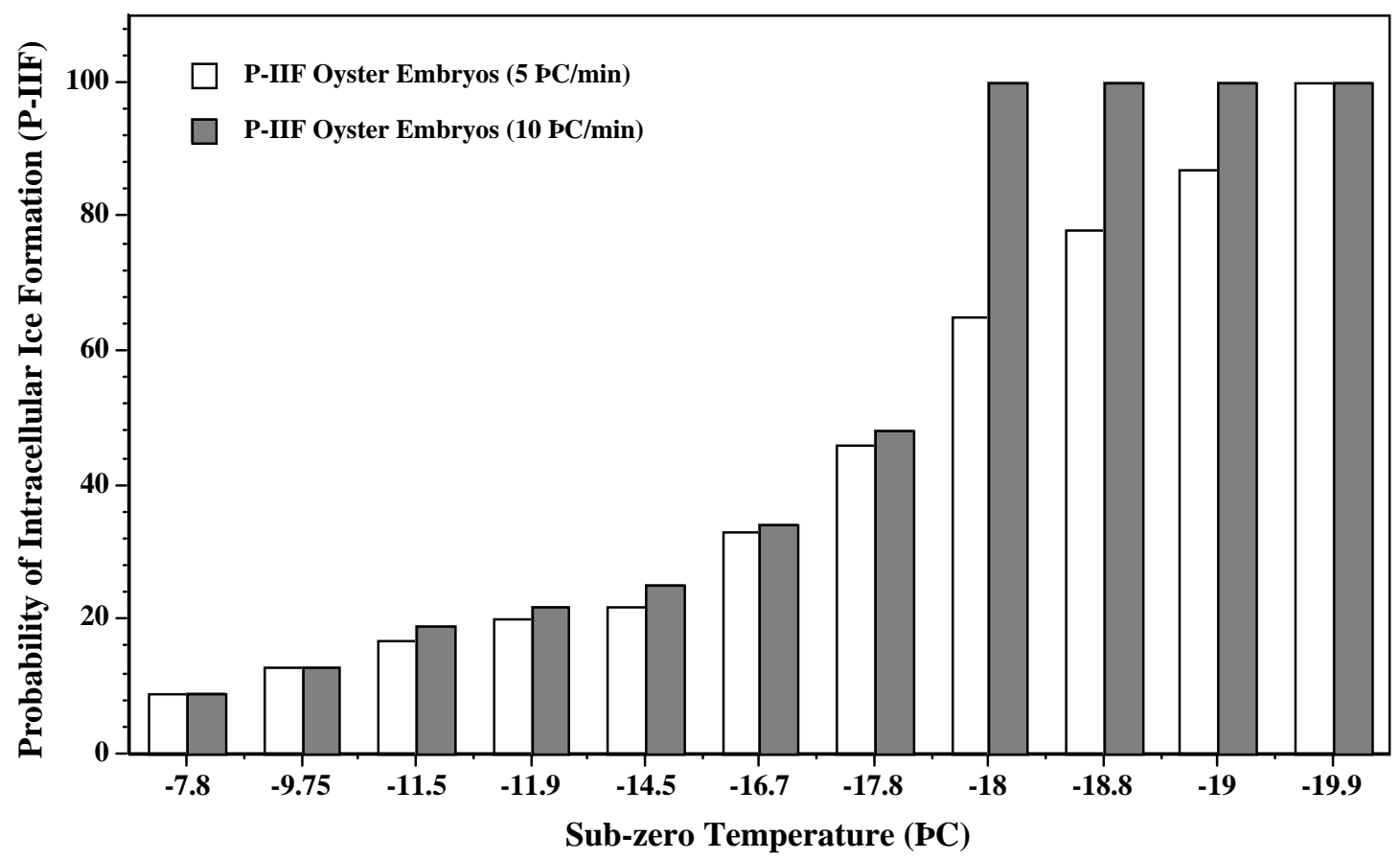

Fig. (3). The relationship between the probability of intracellular ice formation (P-IIF) and sub-zero temperature is shown for Pacific oyster embryos at two different cooling rates $\left(5\right.$ and $\left.10{ }^{\circ} \mathrm{C} / \mathrm{min}\right)$. The unfilled columns represent the data at $5{ }^{\circ} \mathrm{C} / \mathrm{min}$ while the shaded columns represent the corresponding data at $10{ }^{\circ} \mathrm{C} / \mathrm{min}$. The $\%$ of oyster embryos exhibiting IIF is shown on the y-axis while the sub-zero temperature $\left({ }^{\circ} \mathrm{C}\right)$ is shown on the $\mathrm{x}$-axis. Note that the cumulative fraction $(\%)$ of cells exhibiting IIF is presented as a population based measurement and the data is a representation of the cumulative fraction of cells experiencing IIF from all the experiments (or from a population of cells). Hence, no error bars are shown within Fig. (3). 
with an inactive cell volume $\left(\mathrm{V}_{\mathrm{b}}\right)$ of $0.48 \mathrm{~V}_{\mathrm{o}}$ while Tervit et $a l$. [69] reported that ethylene glycol (10\%) and dimethylsulfoxide $(15 \%)$ were the most effective cryoprotectants for oyster oocytes resulting in high post-thaw fertilization rates of $\sim 51 \%$ and $\sim 45 \%$, respectively. Tervit et al. [69] also suggested that the use of Milli-Q water instead of sea water as a base medium, and a 5 minute isothermal hold at either -10 ${ }^{\circ} \mathrm{C}$ or $-12{ }^{\circ} \mathrm{C}$, significantly improved the Oyster oocyte fertilization rates. The data presented in this study suggests that Pacific oysters embryos need to be cooled at rates of $\sim 1$ to 2 ${ }^{\circ} \mathrm{C} / \mathrm{min}$ for optimal post-freeze response. This value is comparable to those published in the literature for mouse and human embryos [70].

\section{Jurkat Cells (Water Transport Measurements)}

Assuming a Jurkat cell to be spherical, the initial (prefrozen) diameter of a Jurkat cell was noted as $12 \pm 1.1 \mu \mathrm{m}$ [45]. To account for any possible variations in the cell diameter between Jurkat cells, the normalized volume of a given Jurkat cell at a given sub-zero temperature was evaluated as a ratio of the experimentally determined diameter at this (sub-zero) temperature to the original diameter of the

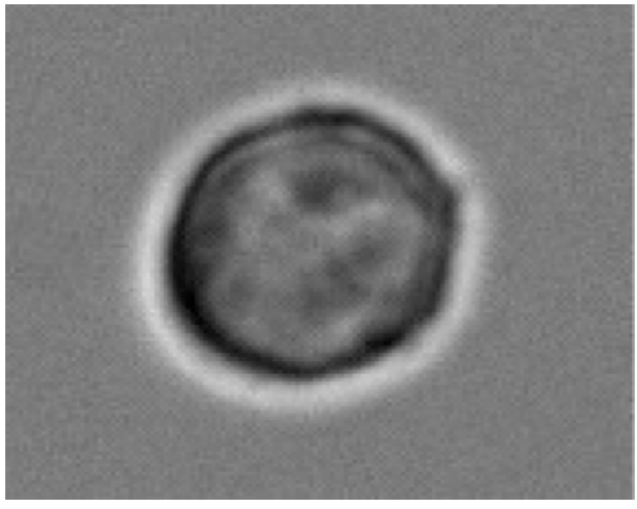

(A)

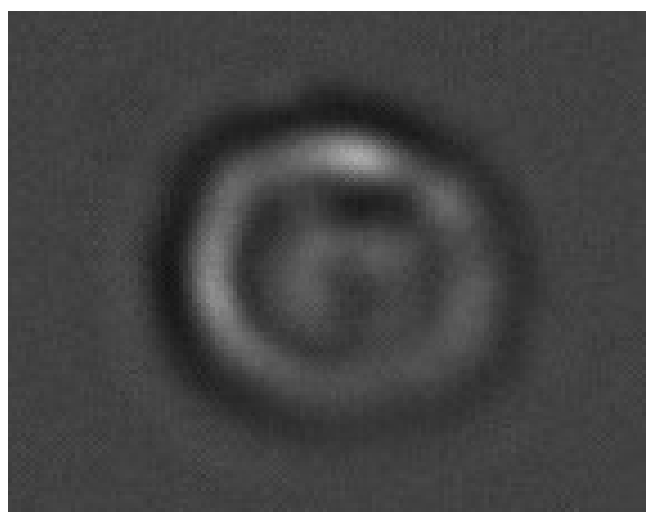

(C) same cell at the initial (pre-frozen) temperature of $23{ }^{\circ} \mathrm{C}$. Any reduction in diameter can be attributed to corresponding reduction in the Jurkat cell volume or to the process of cellular dehydration (water transport). For example, Figs. (4A, 4B and $4 \mathrm{C}$ ) represent a Jurkat cell being cooled at $1{ }^{\circ} \mathrm{C} / \mathrm{min}$ at $\sim 23^{\circ} \mathrm{C},-2{ }^{\circ} \mathrm{C}$ and $-7{ }^{\circ} \mathrm{C}$, respectively. The corresponding reduction in volume as a function of sub-zero temperature was analyzed and plotted, as shown in Fig. (4D). As shown in Fig. (4D), the cellular dehydration process in Jurkat cells terminates at approximately $-7{ }^{\circ} \mathrm{C}$ and the final (fully) dehydrated volume or the osmotically inactive cell volume $\left(\mathrm{V}_{\mathrm{b}}\right)$ was $0.52 \mathrm{~V}_{\mathrm{o}}$. This final osmotically inactive volume for Jurkat cells is in good agreement with earlier published results [45]. By curve-fitting the data shown in Fig. (4D) to the water transport model described earlier, we determined that the $L_{p g}$ of Jurkat cells is $0.20 \mu \mathrm{m} / \mathrm{min}$-atm while the $E_{L p}$ is 69.7 $\mathrm{Kcal} / \mathrm{mole}$ (the goodness of fit was 0.96 ; note that a value of 1 indicates a perfect fit between the experimental data and the numerical simulation). Utilizing the GOCRE, these values translated into an optimal cooling rate of $\sim 2.2{ }^{\circ} \mathrm{C} / \mathrm{min}$ for Jurkat cells.

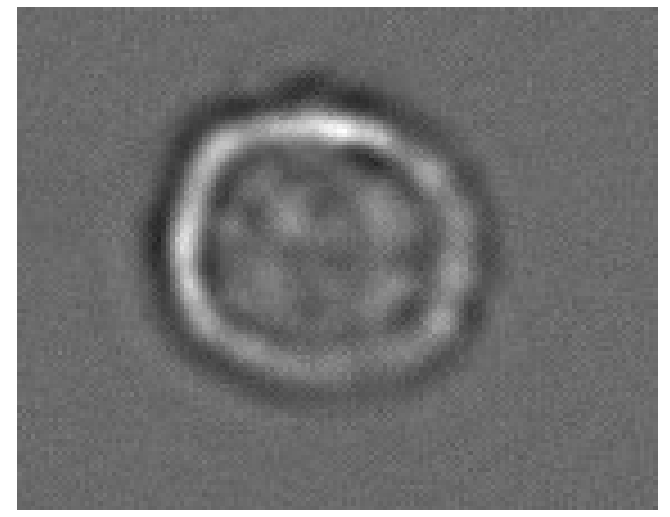

(B)

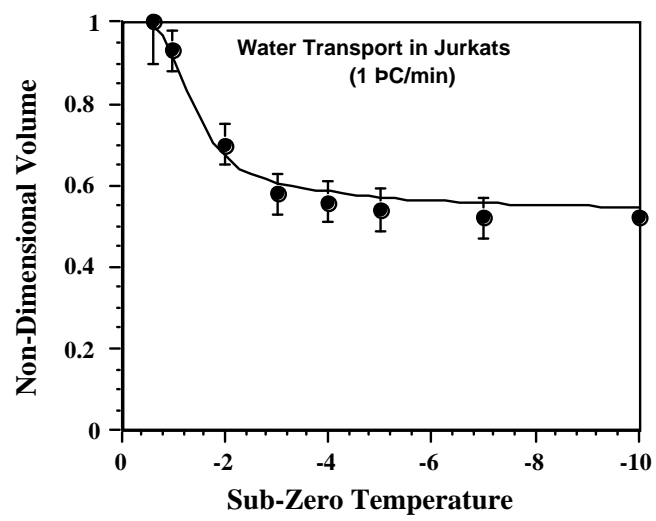

(D)

Fig. (4). Photomicrographs of Jurkat cells being cooled at $1{ }^{\circ} \mathrm{C} / \mathrm{min}$ are shown at various temperatures. Specifically, at room temperature or $23{ }^{\circ} \mathrm{C}(\mathbf{4 A}),-2{ }^{\circ} \mathrm{C}(\mathbf{4 B})$ and $-7{ }^{\circ} \mathrm{C}(\mathbf{4 C})$ are shown. Note the progressive decrease in the cell size as the subzero temperature is decreased and the associated loss of intracellular water. Fig. (4D) shows the relationship between the non-dimensional cell volume and the sub-zero temperature for Jurkats cooled at $1{ }^{\circ} \mathrm{C} / \mathrm{min}$. The filled circles represent the experimentally determined non-dimensional cell volume and were obtained by an analysis of photomicrographs similar to those shown in Figs. (4A to 4C). The water transport model-simulated cooling response at $1{ }^{\circ} \mathrm{C} / \mathrm{min}$ is also shown as a solid line in Fig. (4D). In Fig. (4D), the non-dimensional Jurkat cell volume is shown on the y-axis while the sub-zero temperature $\left({ }^{\circ} \mathrm{C}\right)$ is shown on the $\mathrm{x}$-axis. 


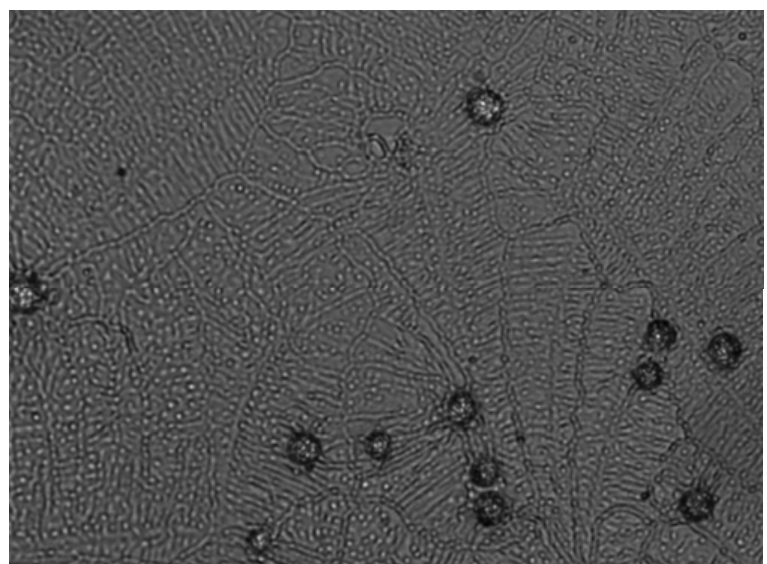

(A)

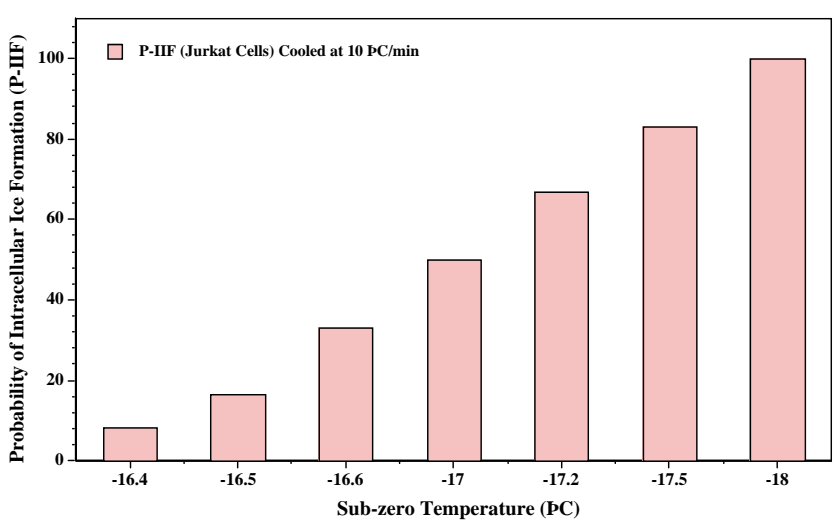

(B)

Fig. (5). Photomicrograph of Jurkat cells being cooled at $10{ }^{\circ} \mathrm{C} / \mathrm{min}$ at a temperature of $-18{ }^{\circ} \mathrm{C}(\mathbf{5 A})$ is shown. Fig. (5B) shows the relationship between the probability of intracellular ice formation (P-IIF) and sub-zero temperature for Jurkat cells being cooled at $10{ }^{\circ} \mathrm{C} / \mathrm{min}$. In Fig. (5B), the \% of Jurkats exhibiting IIF is shown on the $\mathrm{y}$-axis while the sub-zero temperature $\left({ }^{\circ} \mathrm{C}\right)$ is shown on the $\mathrm{x}$-axis. Note that the cumulative fraction (\%) of cells exhibiting IIF is presented as a population based measurement and the data is a representation of the cumulative fraction of cells experiencing IIF from all the experiments (or from a population of cells). Hence, no error bars are shown within Fig. (5B).

\section{Jurkat Cells (IIF Measurements)}

As shown in Fig. (5A), Jurkat cells cooled at $10{ }^{\circ} \mathrm{C} / \mathrm{min}$ to $-18{ }^{\circ} \mathrm{C}$ exhibited a P-IIF of $100 \%$, i.e., all the Jurkat cells experienced IIF when cooled at $10{ }^{\circ} \mathrm{C} / \mathrm{min}$. Jurkat cells experienced IIF within the narrow temperature band between -16 and $-18{ }^{\circ} \mathrm{C}$, when cooled at $10{ }^{\circ} \mathrm{C} / \mathrm{min}$. A plot of P-IIF with sub-zero temperature for Jurkats cooled at $10{ }^{\circ} \mathrm{C} / \mathrm{min}$ is shown in Fig. (5B). Note that the cumulative fraction (\%) of cells exhibiting IIF is presented as a population based measurement and the data is a representation of the cumulative fraction of cells experiencing IIF from all the experiments (or from a population of cells). Hence, no error bars are shown within Fig. (5B).

\section{HeLa Cells (Water Transport Measurements)}

Assuming a HeLa cell to be spherical, the initial (prefrozen) diameter of a HeLa cell was noted as $15 \pm 1.5 \mu \mathrm{m}$ [45]. The water transport analysis for HeLa cells was performed as described earlier for Jurkat cells at a cooling rate of $1{ }^{\circ} \mathrm{C} / \mathrm{min}$. The corresponding reduction in HeLa cell volume as a function of sub-zero temperature was analyzed and plotted, and is shown in Fig. (6A). As shown the cellular dehydration process terminates at approximately $-7{ }^{\circ} \mathrm{C}$ and the final (fully) dehydrated volume was $0.45 \mathrm{~V}_{0}$. This final osmotically inactive volume for $\mathrm{HeLa}$ cells is in good agreement with earlier published results [45]. By curvefitting the data shown in Fig. (6A) to the water transport model described earlier, we determined that the $L_{p g}$ of HeLa cells is $0.05 \mu \mathrm{m} / \mathrm{min}$-atm while the $E_{L p}$ is $20.9 \mathrm{Kcal} / \mathrm{mole}$ (the goodness of fit was 0.97). Utilizing the GOCRE, these values translated into an optimal cooling rate of $\sim 6.5^{\circ} \mathrm{C} / \mathrm{min}$ for HeLa cells.

\section{HeLa Cells (IIF Measurements)}

A plot of P-IIF with sub-zero temperature for HeLas cooled at 15 and $20{ }^{\circ} \mathrm{C} / \mathrm{min}$ is shown in Fig. (6B). As shown in Fig. (6B), HeLa cells cooled at $15{ }^{\circ} \mathrm{C} /$ min exhibited IIF between -2 and $-11.5{ }^{\circ} \mathrm{C}$ while the HeLa cells cooled at 20
${ }^{\circ} \mathrm{C} /$ min exhibited IIF between -2 and $-19.2{ }^{\circ} \mathrm{C}$, respectively. Note that all the HeLa cells did not experience IIF when cooled at either 15 or $20{ }^{\circ} \mathrm{C} / \mathrm{min}$. Approximately, $\sim 81 \%$ and $\sim 94 \%$ of the HeLa cells exhibited IIF when cooled at 15 and $20{ }^{\circ} \mathrm{C} / \mathrm{min}$, respectively. Additional experiments at 10 ${ }^{\circ} \mathrm{C} / \mathrm{min}$ with HeLa cells did not show any evidence of IIF (data not shown).

\section{Relevance of Jurkat and HeLa Cell Measurements to Cryosurgery}

The results presented here are qualitatively similar to those of other cells using cryomicroscopy [48-62] and more specifically to earlier studies on HeLas [50]. Briefly, at low cooling rates, cellular dehydration occurs and as the cooling rate is increased the percentage (and the probability) of cells exhibiting IIF increases. The importance of the P-IIF to cryobiology is related by an observation by Toner [70] that the cooling rate that induces $50 \%$ of the cells to exhibit IIF is optimal, i.e., cooling rates that are above or below this cooling rate are sub-optimal for cryopreservation but conversely, are optimal for cryodestruction. Hence, the P-IIF data obtained for Jurkat cells in the present study indicate that the extensive cellular damage due to IIF will occur when these are cooled $>5^{\circ} \mathrm{C} / \mathrm{min}$ while the corresponding cooling rates for HeLa cells are $>10{ }^{\circ} \mathrm{C} / \mathrm{min}$. Conversely, the water transport data indicates that both these cell types need to cooled at $<1^{\circ} \mathrm{C} /$ min for extensive solute effects or slow cooling injury to occur. These damaging cooling rates $\left(<1{ }^{\circ} \mathrm{C} / \mathrm{min}\right.$ and $>5$ ${ }^{\circ} \mathrm{C} /$ min for Jurkats; $<1{ }^{\circ} \mathrm{C} / \mathrm{min}$ and $>10{ }^{\circ} \mathrm{C} / \mathrm{min}$ for HeLas) are present with in a typical cryosurgical ice-ball, i.e., at regions at the edge of the frozen region or the ice-ball (cooling rates $\left.<1{ }^{\circ} \mathrm{C} / \mathrm{min}\right)$ and at regions close to the inserted ice probe (cooling rates $>5{ }^{\circ} \mathrm{C} / \mathrm{min}$ ). Obviously, the behavior and response of these cells when they are embedded in an extra-cellular tissue matrix (like in a tumor tissue) will be dissimilar to isolated cells, i.e. the cell types used in the present study [71]. And finally, the membrane and protein denaturation during freezing/thawing and the associated injury 


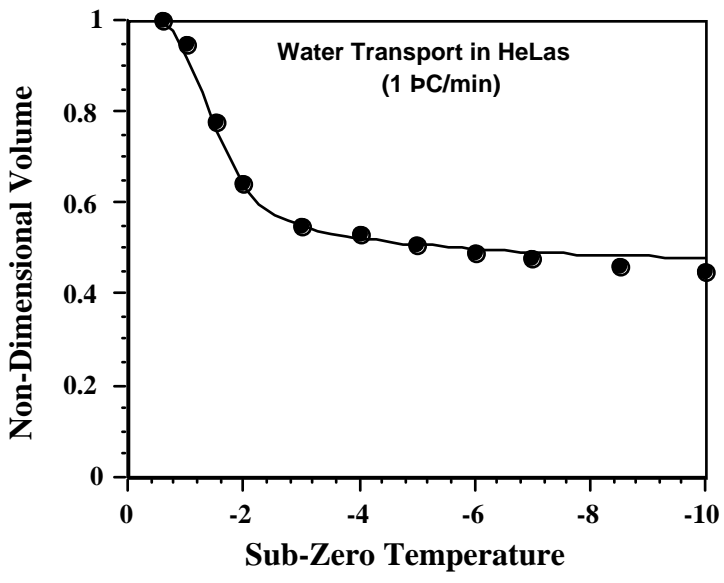

(A)

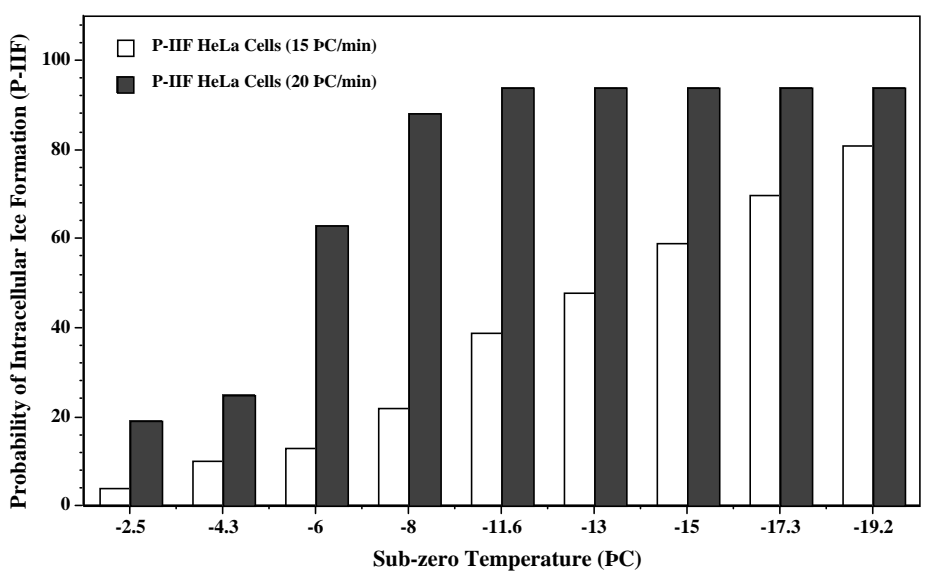

(B)

Fig. (6): 6A shows the relationship between the non-dimensional cell volume and the sub-zero temperature for HeLa cells cooled at 1 ${ }^{\circ} \mathrm{C} / \mathrm{min}$. The filled circles represent the experimentally determined non-dimensional cell volume and were obtained by an analysis of photomicrographs during the freezing process (images not shown). The water transport model-simulated cooling response at $1{ }^{\circ} \mathrm{C} / \mathrm{min}$ is also shown as a solid line in Fig. (6A). In Fig. (6A), the non-dimensional HeLa cell volume is shown on the y-axis while the sub-zero temperature $\left({ }^{\circ} \mathrm{C}\right)$ is shown on the $\mathrm{x}$-axis. Fig. $(\mathbf{6 B})$ shows the relationship between the probability of intracellular ice formation (P-IIF) and sub-zero temperature $\left({ }^{\circ} \mathrm{C}\right)$ for $\mathrm{HeLa}$ cells being cooled at either 15 or $20{ }^{\circ} \mathrm{C} / \mathrm{min}$. In Fig. $(6 \mathbf{B})$, the unfilled columns represent the data at $15{ }^{\circ} \mathrm{C} / \mathrm{min}$ while the shaded columns represent the corresponding data at $20{ }^{\circ} \mathrm{C} / \mathrm{min}$. In Fig. (6B), the $\%$ of HeLa cells exhibiting IIF is shown on the y-axis while the sub-zero temperature $\left({ }^{\circ} \mathrm{C}\right)$ is shown on the $\mathrm{x}$-axis. Note that the cumulative fraction $(\%)$ of cells exhibiting IIF is presented as a population based measurement and the data is a representation of the cumulative fraction of cells experiencing IIF from all the experiments (or from a population of cells). Hence, no error bars are shown within Fig. (6B).

might also play a role in determining the outcome of a cryosurgical protocol [72].

\section{CONCLUSIONS}

Freezing experiments were performed on three different types of cells, Pacific oyster embryos, Jurkat cells and HeLa cells. In this work, IIF through darkening of the cells was observed in Pacific oyster embryos cooled at 5 and 10 ${ }^{\circ} \mathrm{C} / \mathrm{min}$, in Jurkat cells cooled at $10{ }^{\circ} \mathrm{C} / \mathrm{min}$ and in HeLa cells cooled at 15 and $20^{\circ} \mathrm{C} / \mathrm{min}$. Water transport was also measured in Jurkat and HeLa cells at a cooling rate of $1{ }^{\circ} \mathrm{C} / \mathrm{min}$. These observations provide useful information to future researchers who intended to develop successful protocols for cryopreservation (oyster embryos) and cryosurgery (Jurkat and $\mathrm{HeLa}$ ).

\section{ACKNOWLEDGEMENTS}

Financial support provided by the Department of Mechanical Engineering at Louisiana State University is gratefully acknowledged. The authors thank Dr. Todd Monroe and Dr. Julianne Audiffred for help with the Jurkat and HeLa cell culture and cell isolation protocols. Acknowledgements are also due to Dr. Tiersch at the LSU Aquaculture Research Station for help with the collection and isolation procedures for Pacific oyster embryos.

\section{REFERENCES}

[1] Nag KK, Street HE. Carrot embryo-genesis from frozen cultured cells. Nature 1973; 245: 270-2.

[2] Meyer ED, Sinclair NA, Nagy B. Comparison of the survival and metabolic activity of psychophilic and mesophilic yeasts subjected to freeze-thaw stress. Appl Microbiol 1975; 29: 739-44.

[3] McGrath JJ. Preservation of biological material by freezing and thawing. In: Shitzer A, Eberhart RC, Eds. Heat transfer in medicine and biology. New York: Plenum Press 1985.
[4] Harris CL, Toner M, Cravalho EG. Cryopreservation of isolated hepatocytes: intracellular ice formation under various chemical and physical conditions. Cryobiology 1991; 28: 436-44.

[5] Walsh JR. Modeling and design of algal cryopreservation protocols. Ph.D. Dissertation: The University of Texas at Austin 2003.

[6] Bernard A, Fuller BJ. Cryopreservation of human oocytes: a review of current problems and perspectives. Hum Reprod Update 1996; 2: 193-207.

[7] Day SH, Nicoll-Griffith DA, Silva JM. Cryopreservation of rat and human liver slices by rapid freezing. Cryobiology 1999; 38: 154-9.

[8] Oegema TR, Deloria LB, Fedewa M, Bischof JC, Lewis JL. A simple cryopreservation method for the maintenance of cell viability and mechanical integrity of cultured cartilage analog. Cryobiology 1999; 40: 370-5.

[9] Devireddy RV, Olin T, Vincente W, Troedsson MHT, Bischof JC, Roberts KP. Cryopreservation of equine spermatozoa: Optimal cooling rates in the presence and absence of cryoprotective agents. Biol Reprod 2002; 66: 222-31.

[10] Thirumala S, Ferrer MS, Al-Jarrah A, Eilts BE, Paccamonti DL Devireddy RV. Cryopreservation of canine spermatozoa: theoretical prediction of optimal cooling rates in presence and absence of cryoprotective agents. Cryobiology 2003; 47: 109-24.

[11] Thirumala S, Gimble J, Devireddy RV. Transport phenomena during freezing of adipose tissue derived adult stem cells. Biotechnol Bioeng 2005; 92: 372-83.

[12] Amorim CA, Van Langendonckt A, David A, Dolmans MM, Donnez J. Survival of human pre-antral follicles after cryopreservation of ovarian tissue, follicular isolation and in vitro culture in a calcium alginate matrix. Hum Reprod 2009; 24: 92-9.

[13] Arnott J. On the treatment of cancer by the regulated application of an anaesthetic temperature. London: Churchill 1851.

[14] Cooper IS, Lee AS. Cryostatic congelation: a system for producing a limited, controlled region of cooling or freezing of biological systems. J Nerv Ment Dis 1961; 133: 259-63.

[15] Cooper IS. Cryogenic surgery. A new method of destruction or extirpation of benign or malignant tissues. N Engl J Med 1963; 268: 743-9.

[16] Gage AA. Cryosurgery in the treatment of cancer. Surg Gynecol Obstet 1992; 174: 73-92.

[17] Gage AA, Baust J. Mechanisms of tissue injury in cryosurgery. Cryobiology 1998; 37: 171-86. 
[18] Dawber RPR, Colver G, Jackson A. Historic and scientific basis of cryosurgery. In: Cutaneous Cryosurgery. Principles and Practice. London: Martin Dunitz 1997; pp. 15-26.

[19] Bickels J, Meller I, Shmookler BM, Malawer MM. The role and biology of cryosurgery in the treatment of bone tumours. A review. Acta Orthop Scand 1999; 70: 308-15.

[20] Maiwand MO. The role of cryosurgery in palliation of tracheobronchial carcinoma. Eur J Cardio-Thorac Surg 1999; 15: 764-8.

[21] Molisch H. Investigations on the freezing of plants. Cryo-Letters 1982; 3: 331-90

[22] Müller-Thurgau H. Ueber das Gefrieren und Erfrieren der Pflanzen. Landw Jahrb 1880; 9: 133-89.

[23] Lovelock JE. Haemolysis of human red blood cells by freezing and thawing. Biochim Biophys Acta 1953; 10: 414-26.

[24] Mazur P. Cryobiology: the freezing of biological systems. Science 1970; 168: 939-49.

[25] Mazur P, Leibo SP, Chu EHY. A two-factor hypothesis of freezing injury. Exp Cell Res 1972; 71: 345-55.

[26] Thorpe PE, Knight SC, Farrant J. Optimal conditions for the preservation of mouse lymph node cells in liquid nitrogen using cooling rate techniques. Cryobiology 1976; 13: 126-33.

[27] Mazur P. The role of intracellular freezing in the death of cells cooled at supraoptimal rates. Cryobiology 1977; 14: 251-72.

[28] Mazur P. Freezing of living systems: mechanisms and implications. Am J Cell Physiol 1984; 247: C125-C142.

[29] McGrath JJ. Membrane transport properties In: McGrath JJ, Diller KR, Eds. Low temperature biotechnology: emerging applications and engineering contributions. New York: ASME Press 1988; vol. 98: pp. 273-330.

[30] Devireddy RV, Bischof JC. Measurement of water transport during freezing in mammalian liver tissue-part II: the use of differential scanning calorimetry. ASME J Biomech Eng 1998; 120: 559-69.

[31] Devireddy RV, Swanlund DJ, Roberts KP, Bischof JC. Sub-zero water permeability parameters of mouse spermatozoa in the presence of extracellular ice and cryoprotective agents. Biol Reprod 1999; 61: 764-75.

[32] Devireddy RV, Swanlund DJ, Roberts KP, Pryor JL, Bischof JC. The effect of extracellular ice and cryoprotective agents on the water permeability parameters of human sperm plasma membrane during freezing. Hum Reprod 2000; 15: 1125-35.

[33] Ishiguro H, Rubinsky B. Mechanical interaction between ice crystals and red blood cells during directional solidification. Cryobiology 1994; 31: 483-500.

[34] Hagedorn M, Hsu E, Pilatus U, Wildt DE, Rall WF, Blackband SJ. Magnetic resonance microscopy and spectroscopy reveal kinetics of cryoprotectant permeation in a multicompartmental biological system. Proc Natl Acad Sci USA 1996; 93: 7454-9.

[35] Zhang T, Rawson DM. Permeability of the vitelline membrane of zebra-fish (Brachydanio rerio) embryos to methanol and propane1, 2-diol. Cryo-Letters 1996; 17: 273-80.

[36] He Y, Dong Q, Tiersch T, Devireddy R V. Variation in the membrane transport properties and predicted optimal rates of freezing for spermatozoa of diploid and tetraploid oyster, Crassostea gigas. Biol Reprod 2004; 70: 1428-37.

[37] Dong Q, Huang C, Eudeline B, Tiersch TR. Systematic factor optimization for cryopreservation of shipped sperm samples of diploid Pacific Oysters, Crassostrea gigas. Cryobiology 2005; 51: 176-97.

[38] Dong Q, Huang C, Eudeline B, Allen SK Jr, Tiersch TR. Systematic factor optimization for sperm cryopreservation of tetraploid Pacific Oysters, Crassostrea gigas. Theriogenology 2006; 66: 387 403.

[39] Thirumala S, Campbell WT, Vicknair MR, Tiersch TR, Devireddy RV. Freezing response and optimal cooling rates for cryopreserving sperm cells of striped bass, Morone Saxatilis. Theriogenology 2006; 66: 964-73.

[40] Dong Q, Huang C, Tiersch TR. Control of sperm concentration is necessary for standardization of sperm cryopreservation in aquatic species: evidence from sperm agglutination in oysters. Cryobiology 2007; 54: 87-98.

[41] Tiersch TR. Introduction. In: Tiersch TR, Maxik PM, Eds. Cryopreservation in Aquatic Species. Baton Rouge, LA: World Aquaculture Society 2000.

[42] Salinas-Flores L, Adams SL, Lim MH. Determination of the membrane permeability characteristics of Pacific oyster, Crassostrea gi- gas, oocytes and development of optimized methods to add and remove ethylene glycol. Cryobiology 2008; 56: 43-52.

[43] Lin TT, Chao NH, Tung HT. Factors affecting survival of cryopreserved oyster (Crassostrea gigas) embryos. Cryobiology 1999; 39: 192-6.

[44] Pawelec G, Borowitz A, Krammer PH, Wernet P. Constitutive interleukin 2 production by the JURKAT human leukemic $\mathrm{T}$ cell line. Eur J Immunol 1982; 12: 387-92.

[45] Thirumala S, Forman JM, Monroe WT, Devireddy RV. Freezing and post-thaw apoptotic behavior of cells in the presence of palmitoyl nanogold particles. Nanotechnology 2007; 18: 195104.

[46] Barmak K, Harhaj E, Grant C, Alefantis T, Wigdahl B. Human T cell leukemia virus type I-induced disease: pathways to cancer and neurodegeneration. Virology 2003; 308: 1-12.

[47] Epstein MA. Some unusual features of fine structure observed in HeLa cells. J Biophys Biochem Cytol 1961; 10: 153-62.

[48] Anderson MD. Through the microscope: science probes an unseen world. New York: The Natural History Press, Garden City 1965.

[49] Diller KR, Cravalho EG. A cryomicroscope for the study of freezing and thawing processes in biological cells. Cryobiology 1970; 7: 191-9.

[50] McGrath JJ, Cravalho EG, Huggins CE. An experimental comparison of intracellular ice formation and freeze-thaw survival of HeLa S-3 cells. Cryobiology 1975; 12: 540-50.

[51] Diller KR. Quantitative low temperature optical microscopy of biological systems. J Microsc 1982; 126: 9-28.

[52] Schwartz GJ, Diller KR. Osmotic response of individual cells during freezing: II. Membrane permeability analysis. Cryobiology 1983; 20: 542-52.

[53] Scheiwe MW, Körber C. Thermally defined cryomicroscopy and thermodynamic analysis in lymphocyte freezing. Cryobiology 1984; 21:93-105.

[54] Shabana M, McGrath JJ. Cryomicroscope investigation and thermodynamic modeling of the freezing of unfertilized hamster ova. Cryobiology 1988; 25: 338-54.

[55] Cosman MD, Toner M, Kandel J, Cravalho EG. An integrated cryomicroscopy system. Cryo-Letters 1989; 10: 17-38.

[56] Toner M, Cravalho EG, Karel M. Thermodynamics and kinetics of intracellular ice formation during freezing of biological cells. J Appl Phys1990; 67: 1582-93.

[57] Körber CH, Englich S, Rau G. Intracellular ice formation: cryomicroscopical observation and calorimetric measurement. J Microsc 1991; 161: 313-25.

[58] Toner M, Tompkins RG, Cravalho EG, Yarmush ML. Transport phenomena during freezing of isolated hepatocytes. AIChE J 1992; 38: $1512-22$.

[59] Lin TT, Lung K. IIF characteristics of oyster embryos and eggs determined by a feedback controlled directional cryomicroscope. Cryobiology 1995; 32: 566.

[60] Devireddy RV, Raha D, Bischof JC. Measurement of water transport during freezing in cell suspensions using a differential scanning calorimeter. Cryobiology 1998; 36: 124-55.

[61] Diller KR. Bioheat and mass transfer as viewed through microscope. J Biomech Eng 2005; 127: 67-84.

[62] Balasubramanian S, Bischof J, Hubel A. Water transport and IIF parameters for a connective tissue equivalent. Cryobiology 2005; 52: 62-73.

[63] Mazur P. Kinetics of water loss from cells at subzero temperatures and the likelihood of intracellular freezing. J Gen Physiol 1963; 47: 347-69.

[64] Levin RL, Cravalho EG, Huggins CG. A membrane model describing the effect of temperature on water conductivity of erythrocyte membranes at subzero temperatures. Cryobiology 1976; 13: 41529.

[65] Bevington PR, Robinson DK. Data reduction and error analysis for the physical sciences. New York: McGraw-Hill 1992.

[66] Thirumala S, Devireddy RV. A simplified procedure to determine the optimal rate of freezing biological system. J Biomech Eng 2005; 127: 295-300

[67] Gwo JC. Cryopreservation of oyster (Crassostrea gigas) embryos. Theriogenology 1995; 43: 1163-74.

[68] Salinas-Flores L, Adams SL, Wharton DA, Downes MF, Lim MH. Survival of Pacific oyster, Crassostrea gigas, oocytes in relation to intracellular ice formation. Cryobiology 2008; 56: 28-35. 
[69] Tervit HR, Adams SL, Roberts RD, et al. Successful cryopreservation of Pacific Oyster (Crassostrea gigas) oocytes. Cryobiology 2005; 51: 142-51.

[70] Toner M. Nucleation of ice crystals in biological cells. In: Steponkus PL, Ed. "Advances in Low Temperature Biology" London: JAI Press 1993; vol. 2: pp. 1-52.
[71] Hong J, Rubinsky B. Patterns of ice formation in normal and malignant breast tissue. Cryobiology 1994; 31: 109-20.

[72] Wolkers W, Balasubramanian S, Ongstad E, Zec H, Bischof J. Effects of freezing on membranes and proteins in LNCaP Prostate tumor cells. Biochim Biophys Acta 2007; 1768: 728-36.

(c) Acharya and Devireddy; Licensee Bentham Open.

This is an open access article licensed under the terms of the Creative Commons Attribution Non-Commercial License (http://creativecommons.org/licenses/by-nc/3.0/) which permits unrestricted, non-commercial use, distribution and reproduction in any medium, provided the work is properly cited. 